Zoologica Poloniae (2011) 56/1-4: 49-58

DOI: $10.2478 / \mathrm{v} 10049-011-0007-5$

\title{
THE COMMON HAMSTER, CRICETUS CRICETUS (L.) POPULATIONS IN THE LOWER SAN RIVER VALLEY
}

\author{
AgATA BANASZEK ${ }^{1 *}$ and JOANNA ZIOMEK ${ }^{2}$ \\ ${ }^{1}$ Institute of Biology, University of Białystok; Świerkowa 20B, 15-950 Białystok, \\ Poland; banaszek@uwb.edu.pl \\ ${ }^{2}$ Department of Systematic Zoology, Adam Mickiewicz University; Umultowska \\ 89,61-614 Poznań,Poland; jziomek@amu.edu.pl \\ *corresponding author
}

\begin{abstract}
Seven active localities of the common hamster were found in the Lower San River Valley, while in the Tarnogród Plateau the hamsters are not present any longer. The populations on both banks of the San River belong to the Pannonia phylogeographic lineage. The contact between two Polish phylogeographic lineages: E1 and Pannonia, was not found in this area. Although it is not possible to establish currently what was the former distribution of the phylogroups, it is probable that the barrier between them was formed by the Solska Forest. The genetic diversity of the common hamster populations in the Lower San River Valley is lowered, however quite typical for Polish Pannonia populations. The populations of the Lower San River Valley are isolated from the other parts of the species range in Poland. The only possible connection with other populations is through Ukrainian hamsters in Lvov district.
\end{abstract}

Key words: contact zone, ecological barrier, genetic diversity, phylogeographic lineages

\section{INTRODUCTION}

The common hamster (Cricetus cricetus) is an endangered species in Europe. In Central and Western Europe, the hamsters are exclusively connected with the agriculture fields (NECHAY 2000). The changes in agriculture, urbanization and direct prosecution brought up the breakdown of the populations in the second half of the 20th century. The species range has shrunk all over Europe (Weinhold 2008). 
In Poland, the species inhabited all of the central and southern part of the country, except the high mountains. At present, the hamsters can only be found in south-eastern part of the country (SuRdacki 1971, ZiomeK and BanaszeK 2007). This study of the current range of the common hamster in Poland was carried out in the years 2000-2005. At that time, most of the localities found by SURDACKI (1971) were abandoned. The survey in the whole area of the previous range revealed only 103 active localities situated mostly in the Lublin Upland, Roztocze and the Małopolska Upland. Some isolated localities were found in the Krakow-Częstochowa Upland Upper Silesia, and Sandomierz Basin (Zıомек and BANASZEK 2007). Moreover, 146 localities were considered dubious i.e. the presence of hamster could not be ruled out, as the questionnaires and interviews with local farmers were positive, however the authors themselves were not able to find hamster burrows (Ziomek and Banaszek 2007).

One of the areas in which no active sites were found during the country wide survey was the Lower San River Valley and the Tarnogród Plateau (ZiomeK and BANASZEK 2007), although previously both areas were populated by hamsters (SURDACKi 1971). The Tarnogród Plateau is situated on the border between Roztocze and Sandomierz Basin (Fig. 1). This area is of special interest as, potentially, it could be the area of contact between two phylogeographic groups of the common hamster that inhabit Poland (BANAszeK et al. 2010). The Lublin Upland and Roztocze are inhabited by the E1 phylogroup with its origins in Ukraine. This group also crossed the Vistula river and inhabited the northern part of the Małopolska Upland. The southern part of the Małopolska Upland is inhabited by the Pannonia lineage which moved into Poland from the south, from the Carpathian Basin. The populations of this group are also found in the Krakow-Częstochowa Upland, Upper Silesia, and in the Sandomierz Basin (BANASzeK et al. 2010), (Fig. 1). In the Małopolska Upland, the lineages make contact in the central part of the upland; however, the populations do not mix. The lack of contact is established by the ecological barrier formed by a belt of sandy soils and forested areas (BANASZEK et al. 2012).

Another area where the lineages could potentially meet in Poland was the eastern part of the Sandomierz Basin (Fig. 1). Populations of the E1 lineage were found in numerous localities in agriculture areas of the Lublin Upland and Roztocze bordering from the northeast with the Sandomierz Basin. The populations of Pannonia were found in Chyrowski Plateau and Przemyskie Foothills, although there were just three localities. Further to the west, some Pannonian populations were found at the Tarnów Plateau (BANASzeK et al. 2010). However, the hypothesis about the contact of lineages could not be tested as no active hamster sites were found in the Lower San River Valley and the Tarnogród Plateau during the survey in $2000-2005$. Some dubious localities were left only in the Tarnogród Plateau (ZiomeK and Banaszer 2007). In 2008, we received some new information on the common hamster presence in the Lower San River Valley and decided to conduct another, very detailed inventory in this area and neighboring Tarnogród Plateau. Therefore, the aims of this work were the following: 


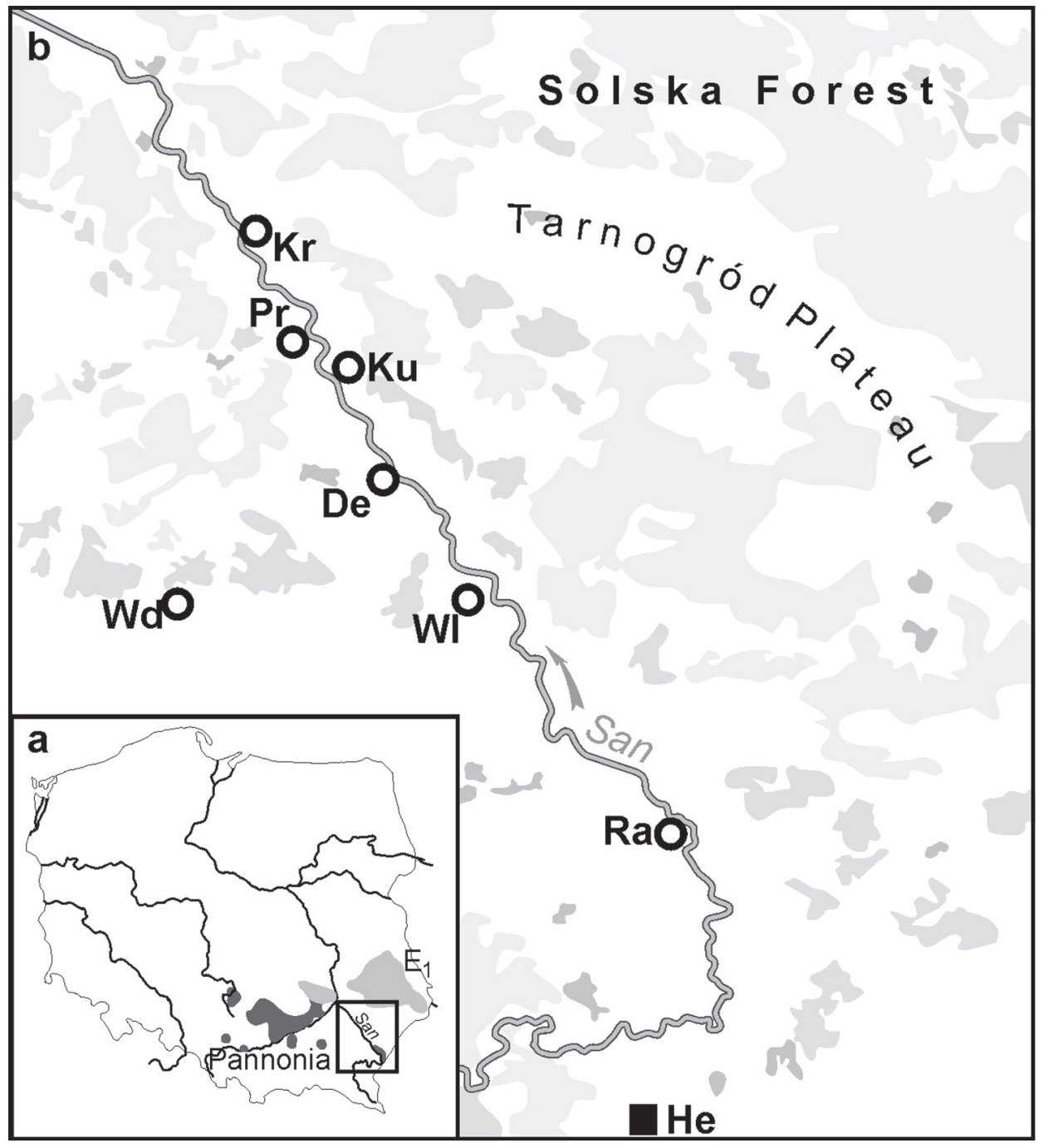

Figure 1. The current range of the common hamster in Poland with the phylogeographic groups indicated, grey area - the E1 lineage, black area - the Pannonia one (a). The active hamster locations found in this survey in the Lower San River Valley indicated by circles and Hermanowice $(\mathrm{He})$ locality by square. The forests indicated by shaded areas.

1. To verify the current distribution of the common hamster in the Lower San River Valley and Tarnogród Plateu

2. To estimate the level of genetic diversity in the common hamster populations

3. To test the hypothesis of the contact of phylogeographic lineages of the common hamster in this area 


\section{MATERIAL AND METHODS}

\section{Localities}

During the years 2009 - 2010 the Lower San River Valley in the part roughly between Radymno and Nisko was checked for the presence of hamsters. The fields were searched after the harvest, and the presence of hamsters was confirmed by the findings of active burrows and by trapping success. In 2011, the Tarnogród Plateu was checked in the same manner. The area of the searched fields was estimated in Map Source 6.15.7 (Garmin).

\section{Collecting hamsters}

A total of 56 hamsters were collected in live traps at six localities in the Lower San River Valley during 2009 - 2010 (Table 1). The trapping was conducted under the permissions of the Minister of the Environment DKFOPogiz4200/IV-18/1117/08/1s Warsaw, Poland and the Local Ethics Committee on Animal Research in Białystok 2008/38 Białystok, Poland. The animals were put under anaesthesia and the ear tips were clipped for the DNA isolation. All of the animals were then released.

\section{DNA extraction and genotyping}

The total genomic DNA was extracted from frozen ear tips using the GenomicMini kit (A\&A Biotechnology). All hamsters were genotyped with 17 microsatellite loci developed for the common hamster: Ccrě3, 4, 10, 11, 12, 13, 15, 17, 19 and 20 (Neumann and Jansmann, 2004, AJ532553 - AJ532554, AJ532556 - AJ532563) and CriCriIPK-01, 03, 05, 06, 07, 09 and 12 (JACOB and MAMmEN, 2006, AM167541, AM167543 - AM167548). The 366bp of the mitochondrial control region $(c t r)$ was sequenced for all animals. The PCR profiles for microsatellite and ctr amplification, the method of microsatellite analysis, and sequencing reactions for ctr were performed according to BANASZEK et al. (2009, 2010, 2011).

\section{Genetic analysis}

For the genetic variability analysis, seven hamsters from the Hermanowice (He) locality situated in the Chyrowski Plateau were used. This locality was described previously in phylogeographic and microsatellite variability research papers (BANASzEK et al. 2009, 2010, 2011). The basic indices of genetic variability (mean number of alleles and heterozygosities for microsatellite loci, haplotype, and nucleotide diversity for the $c t r$ sequences) were calculated in ARLEQUIN 3.5.1.3 (EXCOFFIER and Lischer 2010). Fis (inbreeding coefficient) and its statistical significance were checked in FSTAT 2.9. (GoudET 1995) Hardy-Weinberg equilibrium and population differentiation based on the Fst values were calculated in GENEPOP (RAYMOND and Rousset 1995). In order to identify any potential genetic and geographic barriers in the studied area, the SAMOVA (spatial analysis of molecular variance) was performed (Dupanloup et al. 2002). For SAMOVA, no a priori grouping of the populations is given. If the SAMOVA 
finds the significant structure in the analysed material, it gives the information about the groups formed by the samples and parts of variation between groups of populations, between populations within groups, and within populations.

\section{RESULTS}

\section{Localities and sampling}

Seven active localities were found in the Lower San River Valley (Fig. 1, Table 1). The densities of hamsters, based on the number of active burrows, were low and did not exceed one active burrow per hectare. The only exception was the Radymno population with over three burrows per hectare (Table 1). In the Tarnogród Plateau no hamsters were found.

\section{MtDNA ctr variability}

The $366 \mathrm{bp}$ sequences of the ctr mtDNA were obtained for 56 animals. Additional seven hamsters from the Hermanowice $(\mathrm{He})$ population were included in this material. Three haplotypes were found, two previously published: Po5 (GenBank EU 016 110) and Po6 (EU 016 111) (BANAszeK et al. 2009) and one new, designated Po7 (GenBank JQ 043214) (Table 2). The haplotypes differed by single transitions. Haplotype Po5 predominated in this area with the frequency 0.84 , Po6 occurred in three populations and its total frequency was 0.14 . The new haplotype, Po7, appeared in De population in one individual and its frequency in this area was 0.02 . Haplotype $(\mathrm{H})$ and nucleotide $(\pi)$ diversities for the area were low and equalled 0.280 and $0.091 \%$ respectively.

Table1. The densities of common hamsters in seven active localities in the Lower San River Valley and the numbers of collected hamsters.

\begin{tabular}{lccccc}
\hline Locality & Symbol & $\begin{array}{c}\text { Area } \\
\text { checked } \\
\text { (ha) }\end{array}$ & $\begin{array}{c}\text { No. of } \\
\text { active } \\
\text { burrows }\end{array}$ & $\begin{array}{c}\text { Population } \\
\text { density }\end{array}$ & $\begin{array}{c}\text { No. of } \\
\text { collected } \\
\text { indiv. }\end{array}$ \\
\hline Krzeszów & $K r$ & 21.5 & 14 & 0.65 & 3 \\
Kuryłówka & $K u$ & 28.0 & 16 & 0.57 & 7 \\
Dębno & $D e$ & 19.5 & 3 & 0.15 & 2 \\
Wola Dalsza & $W d$ & 22.5 & 21 & 0.93 & 7 \\
Wola Leżachowska & $W l$ & 25.3 & 12 & 0.47 & 4 \\
Radymno & $R a$ & 35.6 & 120 & 3.37 & 33 \\
Przychojec & $P r$ & 5.6 & 1 & 0.18 & 0 \\
\hline
\end{tabular}


Table 2. The numbers of mtDNA control region haplotypes in the active localities of the common hamster in the Lower San River Valley. ${ }^{1}$ He population was described previously (BANASZEK et al. 2009, 2010, 2011).

\begin{tabular}{lcccc}
\hline \multirow{2}{*}{ Locality } & $\mathrm{n}$ & \multicolumn{3}{c}{ Ctr Haplotypes } \\
\cline { 3 - 5 } & & Po5 & Po6 & Po7 \\
\hline$K r$ & 3 & 3 & & \\
$K u$ & 7 & 6 & 1 & \\
$H e^{l}$ & 7 & 4 & 3 & \\
$D e$ & 2 & 1 & & 1 \\
$W d$ & 7 & 7 & & \\
$W l$ & 4 & 4 & & \\
$R a$ & 33 & 28 & 5 & \\
\hline Total & 63 & 53 & 9 & 1 \\
\hline
\end{tabular}

\section{Microsatellite variability}

Seventeen microsatellite loci were genotyped for all animals. The mean number of alleles ranged from 2.29 to 6.35 with a mean of about 4 alleles per locus (Table 3 ). The remaining indices of the genetic variability were calculated

Table 3. Mean number of alleles (A), observed (Ho) and expected (He) heterozygosity, inbreeding coefficient (Fis), and probability for HW equilibrium test in the Lower San River Valley localities of the common hamster.

\begin{tabular}{lcccccc}
\hline Locality & $\mathrm{n}$ & $\mathrm{A}$ & $\mathrm{Ho}$ & $\mathrm{He}$ & Fis & HWE \\
\hline$K r$ & 3 & 3.24 & - & - & - & - \\
$K u$ & 7 & 4.12 & 0.68 & 0.69 & 0.011 & 0.87 \\
$\mathrm{He}$ & 7 & 4.29 & 0.75 & 0.70 & -0.089 & 0.99 \\
$\mathrm{De}$ & 2 & 2.29 & - & - & - & - \\
$W d$ & 7 & 3.53 & 0.56 & 0.62 & 0.114 & 0.19 \\
$W l$ & 4 & 3.41 & - & - & - & - \\
$R a$ & 33 & 6.35 & 0.72 & 0.73 & 0.018 & 0.28 \\
\hline Mean & & 3.89 & & 0.68 & & \\
\hline
\end{tabular}


Table 4. Pairwise comparison of Fst values between four sampled populations $(\mathrm{n}=7)$ of the common hamster from the Lower San River Valley. All comparisons are statistically significant.

\begin{tabular}{l|ccc} 
& Ku & He & Wd \\
\hline$H e$ & 0.15 & & \\
$W d$ & 0.20 & 0.22 & \\
$R a$ & 0.13 & 0.06 & 0.18
\end{tabular}

for samples of at least seven individuals. The observed and expected heterozygosities did not differ significantly within populations. Similarity of heterozygosities and low Fis values, which were all not significant, might indicate random mating in the populations. All the populations were in Hardy-Weinberg equilibrium (Table 3). Population differentiation based on the Fst value for the whole area was 0.12 , while pairwise Fst values between populations ranged from 0.06 to 0.22 (Table 4). SAMOVA did not find any structure in this area, hence the potential differentiation of the San river banks $(\mathrm{Ku}, \mathrm{He}, \mathrm{Kr}$ - right bank, $W l, W d, R a, D e-1$ eft) was not confirmed.

\section{DISCUSSION}

In this paper, we report seven active localities of common hamster in the Lower San River Valley. Six of them might be related to the Surdacki localities (SURDACKi 1971). During a country-wide survey, these localities were not confirmed (ZIOMEK and BANASZEK 2007), which reflects very low hamster densities in this area. The locality in the Wola Leżachowska fields is a new one, in this area SURDACKI (1971) did not show any hamster sites. The categorization of hamster burrow densities used the following classifications: below 0.2 burrow per hectare the density is very low, $0.2-1$ low, $2-5$ medium, $6-20$ high, $21-50$ very high (Nechay 2000). According to this classification, two localities in the Lower San River Valley (De, Pr) showed very low densities, four localities - low densities, and only one (Ra) was characterized by medium density. The survey was performed in August and September when the hamster densities are the highest at the end of the reproductive season. The low densities might be the result of the unstable habitats in the Lower San River Valley. The San River floods its lower terraces quite regularly and the populations of hamsters are impacted as a result. Still, the soils in the lower terraces are fertile and with good structure, which is the basic demand for stable burrows, hence the hamsters readily settle there. Additionally, it seems that the populations in the Lower San River Valley lost contact with the remaining parts of the common hamster range in Poland. With no influx of individuals from more stable populations, the isolated populations in the valley have high probability of extinction. 
All the populations found in the Lower San River Valley situated on both banks of the river belong to the Pannonia phylogeographic group. The mtDNA ctr haplotypes Po5 and Po6 are characteristic of this group (BANASzeK et al. 2009, 2010). Therefore, contact between phylogroups was not found in the Lower San River Valley as it was hypothesized previously (BANASZEK et al. 2009). The low, frequently flooding valley could serve as a barrier, however, the presence of Pannonia lineage on both banks of the river and lack of genetic structure shown by SAMOVA testifies against it. Moreover, in the Tarnogród Plateau, no active hamster sites were found. We were not able to find any hamsters in the Tarnogród Plateau in 2003 (ZiomeK and BANASZEK 2007), although we decided that with positive information from the farmers, the dubious localities in this area should be left. However, as the second survey in 2011 gave the same results, the dubious localities should now be considered abandoned. Currently, we cannot establish which phylogroup inhabited the Tarnogród Plateau. We also cannot establish which habitat features constituted the barrier between the E1 and Pannonia lineages. By comparison with the Małopolska Upland, where the hamster populations are separated by the area of sandy soils and with a large percentage of forests (BANASZEK et al. 2012), the most probable barrier is the area of Solska Forest. It is the second largest forested area in Poland, situated mostly on sandy soils. In such case, the Tarnogród Plateau was probably inhabited by the Pannonia lineage. However, SURDACKI (1971) reported that during some high density years, the hamsters were present in small agriculture areas inside the Solska Forest. This might indicate the possibility of the E1 lineage migration through this area. Then, the Tarnogród Plateau could be the area of the contact zone.

The genetic variability of the common hamster populations in the Lower San River Valley is quite typical for the populations which started to lose variability not long ago. The breakdown of the common hamster populations in Europe started in the second half of the 20th century (Nechay 2000). The populations which have recently started to lose variability are usually characterized by the disproportion between low mean number of alleles and high heterozygosity levels, as allelic diversity is lost in a quicker manner than heterozygosity (Frankham et al. 2002). Such disproportion was shown for all Polish common hamster populations so far analyzed (BANAszek et al. 2011). Although there is evidence for loss of variability, the populations in the Lower San River Valley are in HW equilibrium and do not show signs of inbreeding. The pattern of the genetic diversity in the Lower San River Valley populations is similar to other small, isolated Pannonian populations in Poland. On the basis of the detailed analysis of one of such populations, we established that it did not show negative effects of genetic variability loss and had a good chance of survival on the condition of the protection of its habitats (BANASZEK and ZiomeK in press). The same conclusion holds for the Lower San River Valley populations.

The Fst value for the whole area is moderate indicating possibilities of gene flow, although for some pairs of populations the Fst is quite high and the genetic exchange between some populations might be restricted. Still, there is 
a natural corridor of migration along the Lower San River Valley, and as such, it should be protected. The Radymno population is of special interest as it harbors large genetic variability and could be the source for dispersal in this area. Although there is some gene flow between populations along the river, the whole system seems to be isolated from the other parts of the species range in Poland. However, the presence of some hamster populations was confirmed after 2000 in Lvov district in Ukraine (RUsin et al. 2011). It is probable that there is still contact with the Ukrainian hamsters through the populations which inhabit the Chyrowski Plateau and Przemyskie Foothills. Further research with genetic analysis of the Ukrainian populations is necessary.

\section{Acknowledgements}

The authors wish to express their gratitude to M.Sc. students Tomasz Buńkowski, Przemysław Gawędzki and Karolina Heronimek, who helped in the field work. Special thanks to Konrad Kata, Jerzy Grzybek, Artur Gerersdorf and Tomasz Łamasz, who provided the information about the common hamster sites in the Lower San River Valley.

The work was financed by the Polish State Committee for Scientific Research under grant no. N N304 168736.

\section{WYSTĘPOWANIE CHOMIKA EUROPEJSKIEGO CRICETUS CRICETUS (L.) W DOLINIE DOLNEGO SANU.}

\section{STRESZCZENIE}

W dolinie dolnego Sanu stwierdzono siedem aktywnych stanowisk chomika europejskiego, podczas gdy nie potwierdzono jego występowania na Płaskowyżu Tarnogrodzkim. Populacje występujące po dwóch stronach Sanu należą do tej samej linii filogeograficznej - Pannonia. Kontakt pomiędzy dwiema występującymiw Polsce liniami filogeograficznymi (E1 i Pannonia) nie został stwierdzony na badanym obszarze. Ustalenie dawnego rozprzestrzenienia obu linii jest obecnie niemożliwe, jednak wydaje się prawdopodobnym, że barierę stanowiła dla nich Puszcza Solska. Zróżnicowanie genetyczne populacji chomika europejskiego w dolinie dolnego Sanu jest obniżone, ale wciąż typowe dla polskich populacji Pannonia. Populacje $\mathrm{z}$ doliny dolnego Sanu są izolowane od pozostałych części zasięgu gatunku w Polsce. Jedyne możliwe połączenie $\mathrm{z}$ innymi populacjami chomika to potencjalny kontakt $\mathrm{z}$ ukraińskimi populacjami w okręgu lwowskim.

\section{REFERENCES}

Banaszek A., Jadwiszczak K.A., Ratkiewicz M., Ziomek J. 2009: Low genetic diversity and significant structuring of the common hamster populations Cricetus cricetus in Poland revealed by the mtDNA control region sequence variation. Acta Theriol., 54: 289-295. 
Banaszek A., Jadwiszczak K.A., Ratkiewicz M., Ziomek J., Neumann K. 2010: Population structure, colonization processes and barriers for dispersal in the common hamster Cricetus cricetus (L.) populations in Poland. J. Zool. Syst. Evol. Res., 48: 151-158.

Banaszek A., Jadwiszczak K.A., Ziomek J., 2011: Genetic variability and differentiation in the Polish common hamster (Cricetus cricetus L.): Genetic consequences of agricultural habitat fragmentation. Mammal. Biol., 76: 665-671.

Banaszek A., Jadwiszczak K.A., Ziomek J., Kaczyńska E., Mirski P. in press: Identification of the barrier to gene flow between phylogeographic lineages of the common hamster Cricetus cricetus. Acta Theriol., in press.

BANASZEK A., ZıOMEK J. in press: Genetic variation and effective population size in an isolated population of the common hamster, Cricetus cricetus. Folia Zool., in press.

Dupanloup I., Schneider S., Excoffier L. 2002: A simulated annealing approach to define the genetic structure of populations. Mol. Ecol., 11: 2571-2581.

Excoffier L., Lischer H. 2010: Arlequin suite ver 3.5: A new series of programs to perform population genetics analyses under Linux and Windows. Mol. Ecol. Res., 10: 564-567.

Frankham R., Ballou J.D., Briscoe D.A. 2002: Introduction to Conservation Genetics. Cambridge University Press, Cambridge.

Goudet J. 1995: Fstat version 1.2: a computer program to calculate Fstatistics J Heredity 86: 485-486.

JАCob S.S., Mammen K. 2006: Eight new polymorphic microsatellite loci for genetic analyses in the endangered common hamster (Cricetus cricetus L.). Mol. Ecol. Notes, 6: 511-513.

Nechay G. 2000: Status of hamsters: Cricetus cricetus, Cricetus migratorius, Mesocricetus newtoni and other hamster species in Europe. Nature and Environment series 106. Council of Europe Publishing, Strasbourg.

Neumann K., Jansman H. 2004: Polymorphic microsatellites for the analysis of endangered common hamster populations (Cricetus cricetus L.). Cons. Genet., 5: $127-130$.

Raymond M., Rousset F. 1995: GENEPOP, version 1.2: population genetics software for exact tests and ecumeniscim. J Hered., 86: 248-249.

Rusin M., Mishta A., Banaszek A. 2011: Distribution of Cricetus cricetus in Ukraine. Proceedings of the $18^{\text {th }}$ Meeting of the International Hamster Workgroup, Strasbourg, France.

SURDACKI S. 1971: The distribution and ranges of the European hamster Cricetus cricetus (Linnaeus, 1758) in Poland. Ann. UMCS, Lublin, Sectio B, 26: 267-285. [In Polish with English summary].

Weinhold U. 2008: Draft European action plan for the conservation of the common hamster (Cricetus cricetus L., 1758). Convention on the conservation of European wildlife and natural habitatas, $28^{\text {th }}$ Meeting of the Standing Committee, Strasbourg: 1-36.

Ziomek J., Banaszek A. 2007: The common hamster, Cricetus cricetus in Poland: status and current range. Folia Zool., 56: 235-242. 